\title{
Research on College Students' Entrepreneurship under the Influence of Internet
}

\author{
Xiaoliang Wu, Yunyun Liang \\ Hainan College of Economics and Business, Hainan Haikou, 571127
}

Key words: college students entrepreneurship internet

\begin{abstract}
Under the background of the internet application, how will entrepreneurship education develop? It can use the internet new information technology to provide information platform for college students, and according to the students' interest in the internet trends to design entrepreneurial platform and entrepreneurial training platform, to help college students solve the difficulties encountered in the current entrepreneurship, and to inject new ideas and new models for college students entrepreneurship education.
\end{abstract}

\section{Research background}

At present, China's internet industry has made rapid development, and ranked the first in the world. The largest composition of internet users is students, the internet has formed an important environment for college students' life and learning, and play a very important role in the entrepreneurial activities of college students. Therefore, in this subject, we take college students as the research object, focusing on the students' internet behavior, experience cognitive role in promoting the formation of entrepreneurial tendency.

\section{Research method}

In the process of the research, we first develop the questionnaire and collect the first-hand data to identify the factors that affect the entrepreneurial trend of college students; Secondly, we analyze the impact of these factors on the entrepreneurial trend of college students; Thirdly, we build the relationship between the impact factors of internet environment and college students' entrepreneurial orientation, and finally provide data support and useful suggestions for the development of college students' internet entrepreneurship communication and training activities.

\subsection{Questionnaire}

A total of 150 questionnaires were issued and 146 were collected. It includes five modules: personal information, the use of network social platform, network shopping experience, network business experience and network entrepreneurship education.

\subsection{Interview}

In addition to the data statistics of the questionnaire, we also randomly interviewed college students. The problem is mainly about the attitude to entrepreneurship, whether there is a business plan, whether to engage in network entrepreneurship and the expectation of business income.

\subsection{Document}

From the network and library, we collect books and materials on college students' entrepreneurial activities and entrepreneurship education, and compare with the statistical data, we will find commonalities and differences to provide support for the thesis.

\section{Data statistics}

\subsection{Statistics of personal information of interviewees}

The personal information of interviewees mainly includes: gender, age, professional, grade and 
family situation. The statistics are as follows.

Table 1: The personal information of interviewees

\begin{tabular}{|c|c|c|c|c|c|c|c|}
\hline \multirow{2}{*}{ gender } & \multicolumn{4}{|c|}{ Male } & \multicolumn{3}{|c|}{ Female } \\
\hline & \multicolumn{4}{|c|}{$95(65 \%)$} & \multicolumn{3}{|c|}{$51(35 \%)$} \\
\hline \multirow{2}{*}{ age } & \multicolumn{2}{|c|}{$18 \sim 20$} & \multicolumn{3}{|c|}{$21 \sim 23$} & \multicolumn{2}{|c|}{ more than 23} \\
\hline & \multicolumn{2}{|c|}{$56(38 \%)$} & \multicolumn{3}{|c|}{$71(49 \%)$} & \multicolumn{2}{|c|}{$19(13 \%)$} \\
\hline \multirow{2}{*}{ professional } & \begin{tabular}{l|l} 
Literature \\
\end{tabular} & \multicolumn{4}{|c|}{ Science and engineering } & Business & Management \\
\hline & $38(26 \%)$ & \multicolumn{3}{|c|}{$36(25 \%)$} & & $35(24 \%)$ & $37(25 \%)$ \\
\hline \multirow{2}{*}{ grade } & Freshman & \multicolumn{3}{|c|}{ sophomore } & \multicolumn{2}{|c|}{ junior } & Senior \\
\hline & $36(25 \%)$ & \multicolumn{3}{|c|}{$38(26 \%)$} & \multicolumn{2}{|c|}{$37(25 \%)$} & $35(24 \%)$ \\
\hline \multirow{2}{*}{$\begin{array}{l}\text { family } \\
\text { situation }\end{array}$} & \multirow{2}{*}{\multicolumn{3}{|c|}{ Poverty }} & \multicolumn{2}{|c|}{ Medium } & \multicolumn{2}{|r|}{ Rich } \\
\hline & & & \multicolumn{3}{|c|}{$92(63 \%)$} & \multicolumn{2}{|c|}{$17(12 \%)$} \\
\hline
\end{tabular}

\subsection{Statistics of the use of communication networking platforms}

All kinds of social activities on the network platform constitute the main amateur life of college students at present. It mainly includes: social networking sites, the studio, Weibo, QQ, wechat. The use of university students against them is as follows.

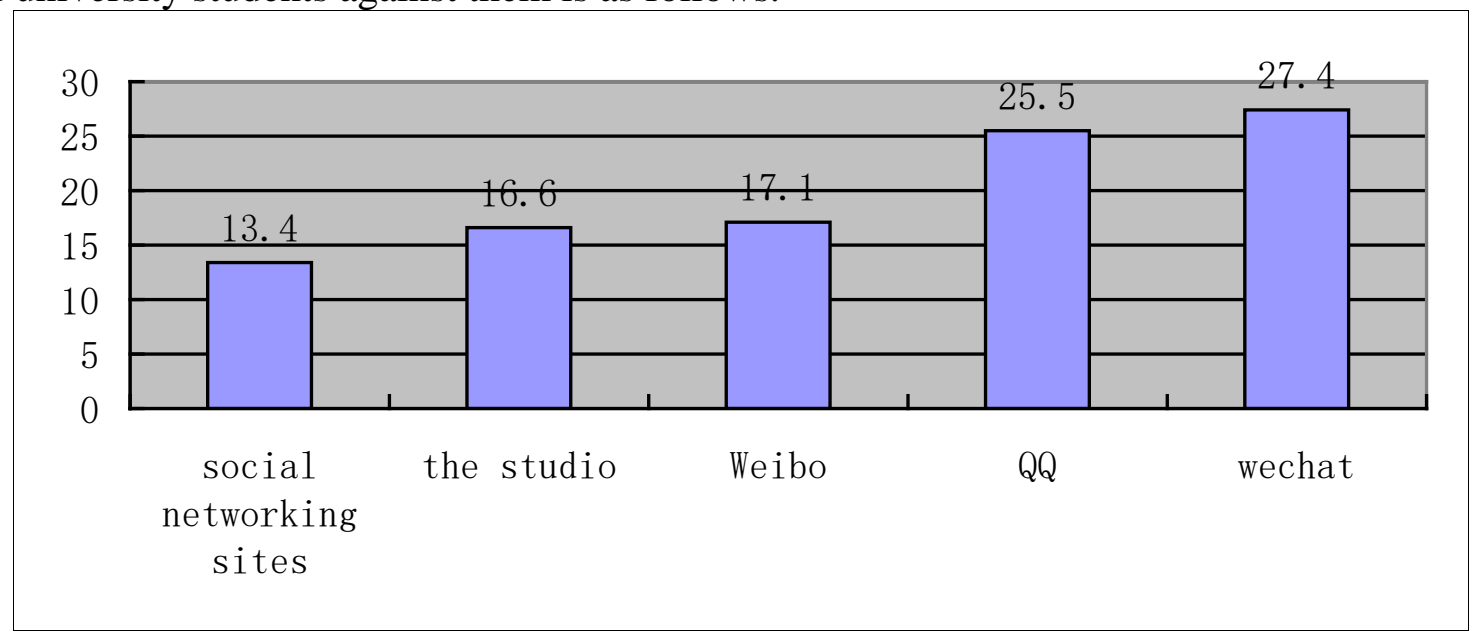

Figure 1: The use of communication networking platforms

\subsection{Statistics of the network shopping experience}

At present, the vast majority of college students have the experience of buying goods on the internet. Their regular shopping sites are: Taobao, Tmall, JingDong, Dangdang. The goods they buy mainly include clothing, life supplies, books and gifts which is as follows.

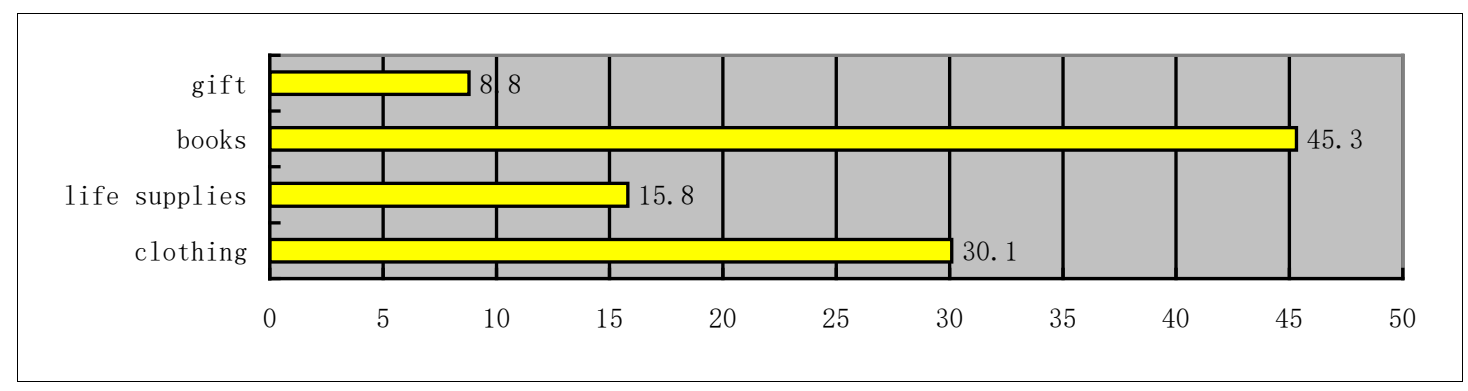

Figure 2: Statistics of the network shopping experience 


\subsection{Statistics of network entrepreneurial experience}

This part of the statistics is very important. About $18.5 \%$ of the respondents had entrepreneurial experience. Their business is mainly sales, express agency, education, training, maintenance, catering services. At the same time, wechat's circle of friends has become the main way for college students to promote their business.

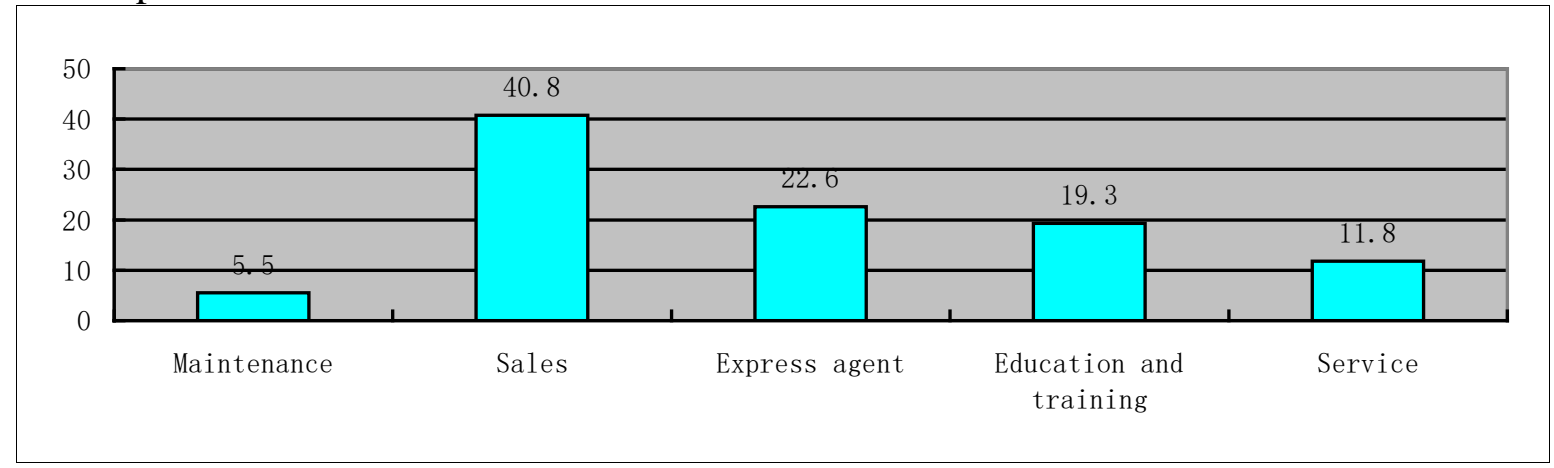

Figure 3: Statistics of the entrepreneurial type

\subsection{Statistics of network entrepreneurship education}

At present, the entrepreneurship education accepted by college students is mainly about the part of the employment guidance course, and the entrepreneurship talks and training organized by the managers from the industry enterprises. Some schools carry out entrepreneurial education courses through the network, but the class is relatively short relative to the professional courses.

Table 2: network entrepreneurship education in university

\begin{tabular}{|c|c|c|c|c|}
\hline \multirow{2}{*}{$\begin{array}{c}\text { Types of } \\
\text { entrepreneurship } \\
\text { education }\end{array}$} & Course & Lec & \multicolumn{2}{|c|}{ Practical guidance } \\
\hline & $50 \%$ & \multicolumn{2}{|c|}{$35 \%$} & \\
\hline \multirow{2}{*}{$\begin{array}{c}\text { Average class } \\
\text { hours }\end{array}$} & Freshman & sophomore & junior & Senior \\
\hline & 0 & 26 & 32 & 32 \\
\hline
\end{tabular}

\section{Analysis}

The personal growth background will have an impact on the creation of entrepreneurial ideas. From the statistics, we can see that older the age rise the more mature the thinking on entrepreneurship. From a professional perspective, students majoring in economic management have more entrepreneurial awareness. At the same time, senior students face more practical problems about entrepreneurship than junior students. In the family situation, students from the middle and affluent families have the possibility of real entrepreneurial activity.

In the business platform, more and more college students choose wechat friends and QQ as the impact site of products. It is closely related to the development of the current network. These platforms have the characteristics of convenient, fast and low cost. It makes the risk of college students in entrepreneurial activities become smaller.

In terms of products, many college students are engaged in online sales of commodities, such as school supplies, skin care products and sporting goods. However, this sales model faces greater competition pressure and can only earn smaller profits. Because of its low cost characteristics, it is suitable for the initial entrepreneurship of college students. At the same time, the product types of college students are relatively single, and the technical content is not high. The vast majority of college students' business is based on simple trade and services.

In the aspect of entrepreneurship education, college students accept relatively less entrepreneurial expertise which is not enough system. At the same time, no one can really help college students carry out long-term entrepreneurial activities, and this help is actually the most important part of college students' entrepreneurial activities. 


\section{Conclusion}

According to the research and analysis, college students entrepreneurship should be more in-depth integration of the network platform. The government gives help and support from policies and even funds to college students engaged in network entrepreneurship. Schools, through the network, carry out more entrepreneurial education and training which needs meet college students' consciousness acceptance ability and aesthetic standard, and make college students really benefit. These will make college students entrepreneurship more practical.

\section{Acknowledgement}

This paper is supported by both of 2017 the project of employment guidance of Hainan College of Economics and Business: Research on the entrepreneurial tendency of higher vocational students under the influence of internet environment(JY2017005) and 2016 the project of Reform of higher education in Hainan province: Research on the type of "Integration into the progress" about the cultivation mode of entrepreneurship education in higher vocational colleges from the perspective of interdisciplinary (Hnjg2016-65).

\section{Reference}

[1]wuqiyun. An investigation on the influencing factors of college students' entrepreneurial orientation [J]. PIONEERING WITH SCIENCE \& TECHNOLOGY MONTHLY. 2008.11

[2]zhaojun yangkeyan. Research on the construction of innovative enterprise information platform under " internet +" environment- taking college students' innovation and entrepreneurship education as an example [J]. Information science. 2016.05 